\title{
Single-suture line placement of a pericardial stentless valve
}

\author{
Alberto Repossini, MD, ${ }^{a}$ Igor Kotelnikov, MD, ${ }^{\text {a }}$ Riad Bouchikhi, MD, ${ }^{a}$ Tiziano Torre, MD, ${ }^{a}$ Bruno Passaretti, MD, \\ Oberdan Parodi, MD, ${ }^{\mathrm{b}}$ and Vincenzo Arena, $\mathrm{MD}^{\mathrm{a}}$
}

Objective: Implantation of bioprostheses in the supra-annular position with the single suture line was first applied by O'Brien to porcine stentless valves. The aim of this study was to evaluate the clinical performance of the Pericarbon Freedom stentless bioprosthesis (Sorin Biomedica Cardio, Saluggia, Italy) implanted in supra-annular position with the single-suture line technique. The single-suture approach for the Pericarbon Freedom stentless bioprosthesis is obtained by trimming away all the extra tissue of the valve inflow side and scalloping the outflow side.

Methods: Between February 2002 and August 2004, a total of 65 consecutive patients at our institution (48\% male, mean age $69 \pm 12$ years) underwent aortic valve replacement with Pericarbon Freedom stentless bioprostheses implanted with a single suture line. Most recurrent etiology was senile degeneration (80\%). Pericarbon Freedom $25-\mathrm{mm}$ and $27-\mathrm{mm}$ valves were the most frequently implanted. Thirty patients had concomitant procedures (mainly coronary artery bypass grafting, 16 patients). Overall crossclamp time was $76 \pm 21$ minutes.

Results: All patients survived intervention. One patient died early of multiorgan failure (postoperative day 16). There were 4 early non-valve-related complications and no late complications at a mean follow-up of $491 \pm 270$ days. Four patients showed trivial central prosthetic regurgitation at intraoperative transesophageal echocardiography; among these cases, only 1 was confirmed at 6-month transthoracic echocardiography. At postoperative echocardiographic assessment, mean pressure gradient for the 25- through $29-\mathrm{mm}$ size group was $10.2 \pm 7.1 \mathrm{~mm} \mathrm{Hg}$, and peak pressure gradient was $18.1 \pm 12.3 \mathrm{~mm} \mathrm{Hg}$.

Conclusion: Our initial experience combined a well-established supra-annular implantation technique with the Pericarbon Freedom stentless bioprosthesis, a latestgeneration pericardial stentless valve. The combination showed excellent results in terms of safety and reliability, although this technique required adequate experience.

From Cardiac Surgery, Cliniche Humanitas Gavazzeni, Bergamo, Italy, ${ }^{a}$ and Institute of Clinical Physiology of the National Council of Research, Pisa, Italy. ${ }^{\mathrm{b}}$

Received for publication Dec 17, 2004; revisions received July 5, 2005; accepted for publication July 19, 2005.

Address for reprints: Alberto Repossini, MD, Cliniche Humanitas Gavazzeni, Via Mauro Gavazzeni No. 21, 24125 Bergamo, Italy (E-mail: alberto.repossini@gavazzeni.it).

J Thorac Cardiovasc Surg 2005;130:1265-9

$0022-5223 / \$ 30.00$

Copyright $\odot 2005$ by The American Association for Thoracic Surgery

doi:10.1016/j.jtcvs.2005.07.045
Clinical outcomes are similar to those obtained with other techniques, with satisfactory hemodynamic performance.

$\mathrm{S}$ ince the introduction of stentless bioprostheses for aortic valve replacement, ${ }^{1}$ a variety of models have been made available. ${ }^{2-4}$ According to O'Brien, ${ }^{5}$ the ideal stentless prosthesis should have no synthetic materials, preserve the aortic root dynamics, restore flexibility and distensibility of the native valve annulus after decalcification, and have minimal xenograft aortic wall, short implantation time, and excellent hemodynamic performance to facilitate the recovery of left ventricular function.

With this in mind, we investigated the use of the Pericarbon Freedom (PF) stentless bioprosthesis (Sorin Biomedica Cardio, Saluggia, Vercelli, Italy) with a simplified supra-annular implantation technique. The prosthesis, available since 


\section{Abbreviations and Acronyms \\ $\mathrm{PF}=$ Pericarbon Freedom}

1991, consists of cross-linked bovine pericardium and has been redesigned in 2000 with the addition of a posttreatment step aimed at removing aldehyde residues. ${ }^{6}$ The valve design includes pericardium only, which forms the leaflets and extends toward inflow and outflow to allow surgical suture placement.

The PF bioprosthesis is provided by the manufacturer with extra tissue, allowing intraoperative tailoring for adaptation to local anatomy and the surgeon's technique. The valve has been implanted with two suture lines (interrupted or continuous stitches on the inflow side and continuous stitches on the outflow side).$^{7,8}$ The alternative single-suture line technique allows correct supra-annular positioning of the prosthesis, avoiding any nonvalvular tissue in the outflow tract.

\section{Methods}

\section{Operative Technique}

The patient is placed on normothermic cardiopulmonary bypass with a central temperature of $37^{\circ} \mathrm{C}$. Myocardial preservation is achieved by antegrade cold (St. Thomas' Hospital) crystalloid cardioplegia through the coronary ostia at 700 to $1000 \mathrm{~mL}$. Additional $300-\mathrm{mL}$ doses are repeated every 30 minutes. Transverse aortic incision is made about $1 \mathrm{~cm}$ above the sinotubular junction, wide enough to completely visualize the valve. Separation of the aorta from the pulmonary common trunk is mandatory. After excision of the valve and decalcification of the annulus, the aortic orifice is measured with a Hegar probe. The prosthetic valve is chosen according to the rule of one size more or $2 \mathrm{~mm}$ larger than the orifice. The single-suture approach is made possible by trimming away all the extra tissue of the valve inflow side and scalloping the outflow side (Figure 1). The valve assembly suture is preserved and is anchored with an extra stitch on the external side of the corresponding commissure, to be placed at the left noncoronary commissure of the native annulus. No rinsing in saline solution is necessary, because the valve is already prepared for implantation.

The implantation surgical technique is derived from O'Brien ${ }^{9,10}$ as follows: three equidistant 4-0 polypropylene sutures on a small taper-cut semicircular needle are placed in supra-annular position near the midpoint, at 2 to $3 \mathrm{~mm}$ from the host annulus of each sinus, exiting further out in the supra-annular sinus wall (Figure 2). Placement of the sutures below or through the annulus should be avoided. Once the valve is seated just above the host annulus in a supra-annular position, each of the three sutures must be tied, leaving equal lengths, six in all, that are used to suture the valve to the host along and up to the top of the commissures, starting with the right coronary sinus $(A)$, the left coronary sinus $(B)$, and then the noncoronary sinus ( $C$, Figure 3$)$.

A moderate traction on the valve during suturing makes easier the supra-annular running suture. The valve is secured in place with deep, almost full-thickness bites to the host aortic wall (Figure 4). Care should be taken to avoid needle damage to the leaflet tissue.

Both sutures from each side are prolonged to the top of the commissure, with an ending knot being placed outside the aorta on
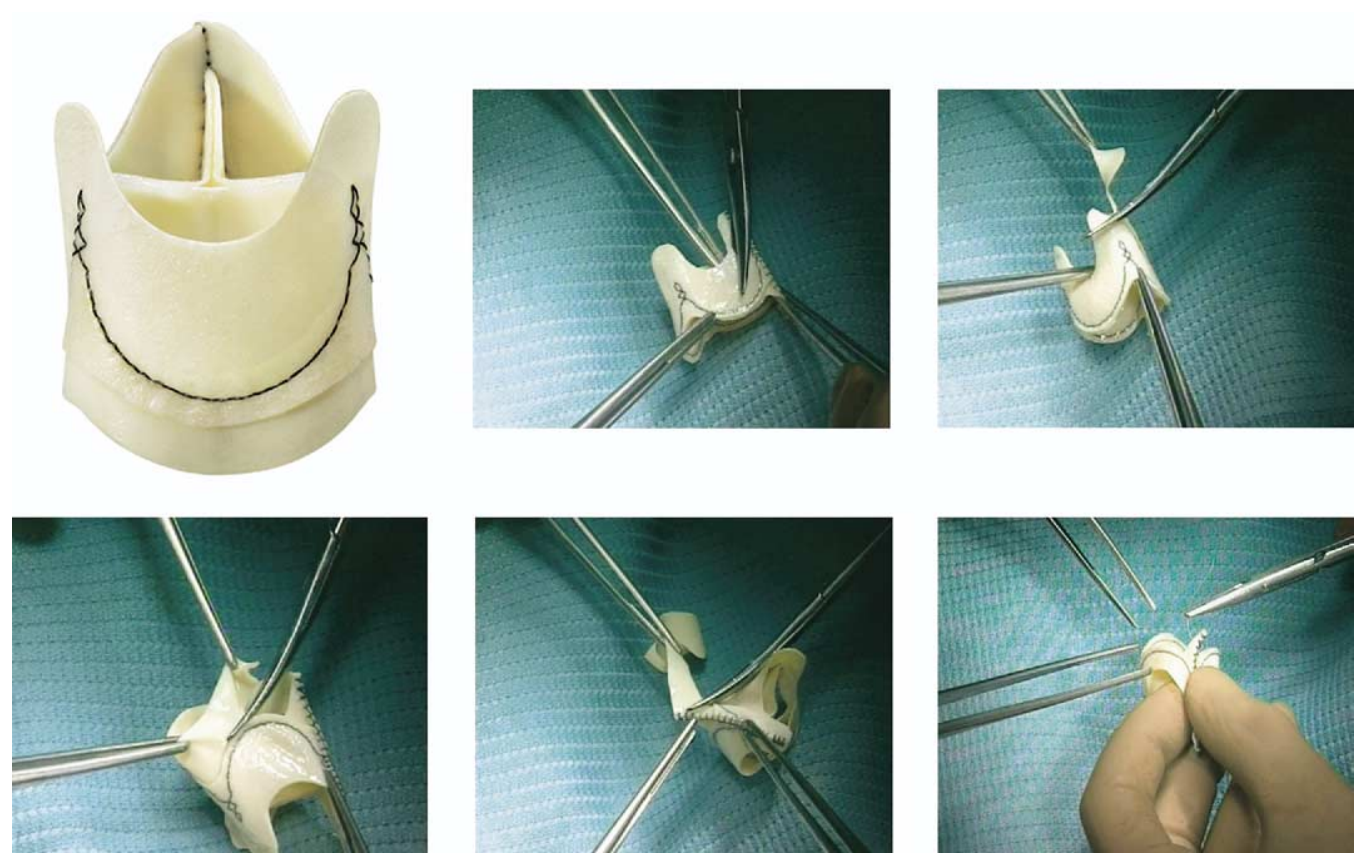

Figure 1. Outflow scalloping and inflow trimming. 


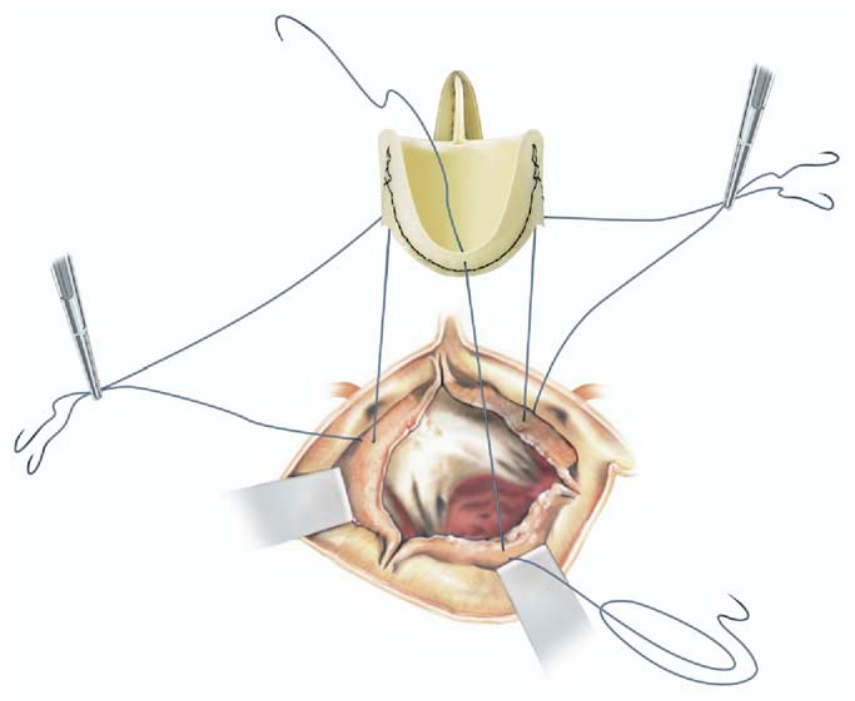

Figure 2. Continuous suture line for subcoronary attachment: first step.

a polytetrafluoroethylene felt. Aortotomy is closed in a standard way with a 5-0 polypropylene running suture.

\section{Indications and Contraindications}

The indications for the PF stentless for supra-annular implantation are as follows: (1) Elderly patients with symmetric aortic root and trileaflet valve-sinus anatomy are the ideal patients. (2) Patients older than 60 years are candidates for this valve. Younger patients wishing to avoid anticoagulation and a mechanical valve and those for whom a homograft is not available may be candidates. (3) Patients

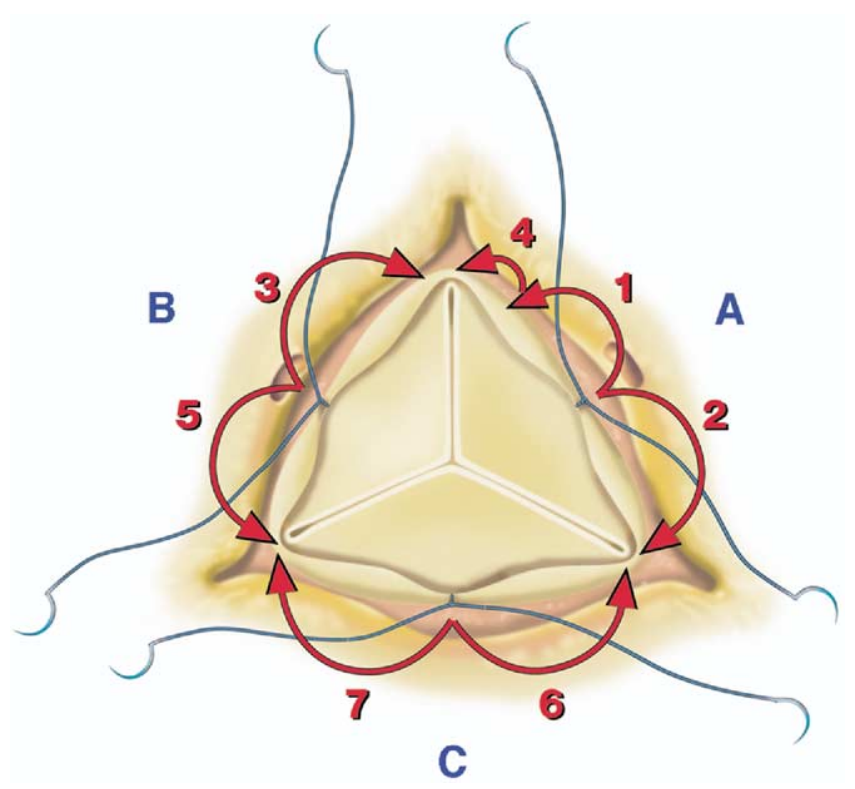

Figure 3. Continuous suture line order for subcoronary attachment.

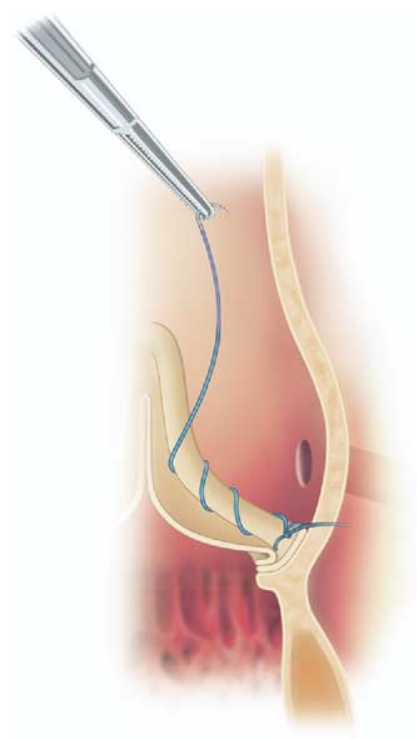

Figure 4. Continuous suture line for subcoronary attachment.

with active endocarditis without periannular abscesses are candidates. The single rare contraindication to the use of this technique is massive calcification of the aortic sinus wall and root, which makes the supra-annular suturing impossible.

In addition to the preceding, two particular features should also be taken into account. Bicuspid valve is not a real contraindication, although directly opposing coronary ostia (ie, $180^{\circ}$ ) may present a difficult orientation of the valve toward the coronary ostia. In case of concomitant aortic ectasia with dilatation of the sinotubular junction ( $>2 \mathrm{~mm}$ larger than the annulus), ascending aorta replacement is mandatory to avoid valve incompetence.

\section{Study Population}

Between February 2002 and August 2004, a total of 65 consecutive patients received the PF stentless valve with a single-suture line implant technique for aortic valve replacement. All implantations were performed by a single surgeon (A.R.). The study comprised 31 male and 34 female patients ranging in age from 26 to 87 years (mean $69 \pm 12$ years). Informed consent was requested from the patients in all cases, according to the rules and regulations of the internal review board of our institution.

Preoperative and intraoperative transesophageal echocardiographic and postoperative echocardiographic analyses were carried out at 1 week after implantation and again at 6 months. In addition to the usual gradient measurements, effective orifice area was also calculated. Clinical status and both type and frequency of postoperative complications were evaluated on the basis of the revised guidelines. ${ }^{11}$ Mean follow-up was $491 \pm 270$ days (range 987-29 days). Completeness of the follow-up was $100 \%$. Color Doppler echocardiography was performed with a Philips Sonos 5500 system (Philips Medical System, Eindhoven, The Netherlands) equipped with a $2.5-$ to $3.5-\mathrm{MHz}$ transducer. Standard M-mode and 2-dimensional measurements were collected according to the criteria of the American Society of Echocardiography. ${ }^{12}$ All Dopp- 
TABLE 1. Etiology of valve disease

\begin{tabular}{lrr}
\hline & No. & $\%$ \\
\hline Senile degeneration or calcification & 52 & 80 \\
Congenital monocuspid or bicuspid valve & 6 & 9 \\
Endocarditis & 3 & 5 \\
Rheumatic & 3 & 5 \\
Degenerative myxomatosis & 1 & 1 \\
\hline
\end{tabular}

ler measurements were averaged for more than three cycles in patients with sinus rhythm or more than five cycles in those with atrial fibrillation.

The reasons for valve replacement are shown in Table 1. Concomitant surgery was performed in 30 cases $(46 \%)$. The most common procedure was coronary artery bypass grafting in 16 patients (Table 2).

Valve size distribution was as follows: 2 size $21 \mathrm{~mm} \mathrm{(3 \% ),} 3$ size $23 \mathrm{~mm}(5 \%), 25$ size $25 \mathrm{~mm}$ (38\%), 29 size $27 \mathrm{~mm} \mathrm{(45 \% ),} \mathrm{and}$ 6 size $29 \mathrm{~mm}(9 \%)$. A bicuspid valve was found in 6 cases; this was not considered a contraindication for a stentless valve.

\section{Results}

There was 1 early death (1.5\%), of multiorgan failure on postoperative day 16 . The patient, aged 80 years and with low ventricular function (ejection fraction 35\%) underwent aortic valve replacement, mitral annuloplasty, myocardial revascularization, and radiofrequency ablation for atrial fibrillation. Death occurred after a complicated postoperative course with low cardiac output and fatal multiorgan failure. Postoperative echocardiography showed normal aortic valve function.

Mean implantation time was $30 \pm 8$ minutes. Mean crossclamp times were $62 \pm 18$ minutes for patients without concomitant procedures and $76 \pm 21$ minutes overall.

Early morbidity included 4 patients $(6.1 \%)$ with non-valverelated complications: 1 pacemaker implantation in a patient with associated tricuspid repair, 2 renal or respiratory transient failures, and 1 transient low cardiac output syndrome necessitating intravenous inotropic support. One female patient, aged 67 years and with associated myocardial revascularization, had endocarditis with extensive periannular abscess 2 months after the operation. Nevertheless, no aortic regurgitation was present, and at reoperation the prosthesis was found to be firmly anchored to the aortic wall. The postoperative course was uneventful, as was the follow-up. No other late complications were reported at follow-up. No late deaths occurred.

\section{Echocardiographic Analysis}

Four patients had trivial central prosthetic regurgitation at intraoperative transesophageal echocardiography. Only 1 case was confirmed at 6-month echocardiographic examination.

Peak pressure transvalvular gradient related to the 25through $29-\mathrm{mm}$ size group (92.3\% of the patient cohort) at
TABLE 2. Concomitant procedures

\begin{tabular}{lrr}
\hline & No. & $\%$ \\
\hline Coronary artery bypass grafting & 16 & 24.6 \\
Resection of aortic aneurysm & 6 & 9.2 \\
Tricuspid or mitral valve repair & 6 & 9.2 \\
Septal myectomy & 1 & 1.5 \\
Radiofrequency ablation & 1 & 1.5 \\
\hline
\end{tabular}

1 postoperative week was $18.1 \pm 12.3 \mathrm{~mm} \mathrm{Hg}$. Mean aortic transvalvular gradients were $10.2 \pm 7.1 \mathrm{~mm} \mathrm{Hg}$ at 1 postoperative week and $8.0 \pm 4.3 \mathrm{~mm} \mathrm{Hg}$ at 6 months. Effective orifice area at 6 months was $2.14 \pm 0.50 \mathrm{~cm}^{2}$. Mean pressure gradients and effective orifice areas for the 21through 29-mm sizes are reported in Table 3.

\section{Discussion}

This is the first clinical application of a true supra-annular technique with a single suture line, as described by O'Brien $^{9,10}$ for the CryoLife-O'Brien porcine stentless valve (CryoLife Inc, Kennesaw, Ga), on a pericardial stentless valve. The early results of the preliminary series of the PF stentless valve with single-suture line implantation technique have been satisfactory. Clinical outcomes were similar to those obtained with other techniques ${ }^{7,14}$; hemodynamic performance was excellent, and residual regurgitation was negligible. Overall implantation time was dramatically reduced.

In clinical practice, the PF stentless valve is optimal for supra-annular implantation for virtually all patients who otherwise would be receiving a stented bioprosthesis. In our consecutive series, no patient was excluded for technical or anatomic reasons.

The supra-annular positioning with PF stentless bioprosthesis shows many advantages. The effective orifice area is maximized, allowing $100 \%$ orifice-annulus match and the implantation of the largest valve orifice available. The blood flow from the ventricle to the aorta is streamlined laminar, and the transvalvular gradients are as low as those of an allograft aortic valve. We report a mean gradient of $10.4 \pm$ $5.6 \mathrm{~mm} \mathrm{Hg}$ for a $25-\mathrm{mm}$ valve (annulus diameter $23 \mathrm{~mm}$ )

TABLE 3. Results of transthoracic echocardiography for 21- to 29-mm sizes at 6-month follow-up

\begin{tabular}{lcc}
\hline Label size & $\begin{array}{c}\text { Mean pressure } \\
\text { gradient }(\mathbf{m m ~} \mathbf{~ H g})\end{array}$ & $\begin{array}{c}\text { Effective orifice } \\
\text { area }\left(\mathbf{c m}^{\mathbf{2}}\right)\end{array}$ \\
\hline $21 \mathrm{~mm}(\mathrm{n}=2)$ & $13.5 \pm 2.1$ & $1.7 \pm 0.5$ \\
$23 \mathrm{~mm}(\mathrm{n}=3)$ & $12.7 \pm 5.8$ & $1.9 \pm 0.6$ \\
$25 \mathrm{~mm}(\mathrm{n}=25)$ & $10.4 \pm 5.6$ & $2.0 \pm 0.5$ \\
$27 \mathrm{~mm}(\mathrm{n}=29)$ & $6.5 \pm 4.3$ & $2.2 \pm 0.5$ \\
$29 \mathrm{~mm}(\mathrm{n}=6)$ & $5.0 \pm 3.2$ & $2.4 \pm 0.4$ \\
\hline
\end{tabular}


and an effective orifice area of $2.0 \pm 0.5 \mathrm{~cm}^{2}$. For comparison, in a local retrospective cohort, the $25-\mathrm{mm}$ valve, with two-suture technique, had a mean gradient of $12.1 \pm 4.2$ $\mathrm{mm} \mathrm{Hg}$ and an effective orifice area of $1.9 \pm 0.4 \mathrm{~cm}^{2}$.

In making a comparison between the two implantation techniques, it should be noted that for a given annular diameter, the supra-annular placement allows a size larger valve. Moreover selecting a valve a size larger than the host annulus maximizes the leaflet coaptation. The stress on the suture line is better absorbed, avoiding the chiseling effect that arises when the stentless valve is implanted in intraannular position. ${ }^{13}$

Bovine pericardium is resistant and fully retains the sutures without any risk of tearing, as has been reported with the aortic porcine wall. ${ }^{15}$ In addition, it is smooth and thin and adapts well to the host tissue, minimizing the risks of perivalvular leaks. Leaks were not observed in any cases in our series.

Moreover, there is no valve tissue inside the annulus and in the outflow tract except the leaflets, which are supraannularly anchored to the aortic wall. Trimming away all the prosthetic pericardial tissue of the inflow tract is important, because no tissue has to be fixed below the leaflets and a single continuous suture line is sufficient to anchor this valve into place.

Placement of the sutures below or through the annulus should be avoided, because intra-annular implantation could have a negative effect on transvalvular gradients. Deep, almost full-thickness bites of the host aortic wall are recommended to secure the valve into place. Deep, broad bites on the outflow pericardial strips are to be performed as well, close to the leaflet attachment and to the black assembling suture. In this way there should be virtually no potential space behind the commissural posts and no ledge underneath the leaflet from the ventricular aspect, with no projection of tissue into the orifice during systole.

The single-suture line technique avoids any periprosthetic dead space between prosthetic valve and native aortic wall. Last but not least, a single continuous suture line is simple and quick, saving time, which is especially advantageous when concomitant cardiac procedures are required.

Our experience combines a well-established truly supraannular implantation technique with a latest-generation pericardial stentless valve that is now available pretrimmed (Freedom Solo).
These early favorable results need to be borne out by longer and more comprehensive studies of larger groups.

\section{References}

1. David TE, Ropchan GC, Butany JW. Aortic valve replacement with stentless porcine bioprosthesis. J Card Surg. 1988;3:501-5.

2. O'Brien MF. Composite stentless xenograft for aortic valve replacement: clinical evaluation of function. Ann Thorac Surg. 1995;60(2 Suppl):S406-9.

3. Westaby S, Amarasena N, Ormerod O, Amarasena GA, Pillai R. Aortic valve replacement with the Freestyle stentless xenograft. Ann Thorac Surg. 1995;60(2 Suppl):S422-7.

4. Casabona R, De Paulis R, Zattera GF, di Summa M, Bottone W, Stacchino C, et al. Stentless porcine and pericardial valve in aortic position. Ann Thorac Surg. 1992;54:681-5.

5. O'Brien MF, Gardner MA, Garlick RB, Davison MB, Thomson HL, Burstow DJ. The Cryolife-O'Brien stentless aortic porcine xenograft valve. J Card Surg. 1998;13:376-85.

6. Stacchino C, Bona G, Bonetti F, Rinaldi S, Della Ciana L, Grignani A. Detoxification process for glutaraldehyde-treated bovine pericardium: biological, chemical and mechanical characterization. J Heart Valve Dis. 1998;7:190-4.

7. Westaby S, Jin X, Vaccari G, Katsumata T. The Sorin stentless pericardial valve: implant technique and hemodynamic profile. Semin Thorac Cardiovasc Surg. 1999;11:62-8.

8. Bonacchi M, Giunti G, Prifti E, Rostagno C, Bini M, Frati G, et al. Early postoperative outcome and hemodynamic performance of the Sorin Pericarbon stentless aortic valve. J Heart Valve Dis. 2002;11:703-9.

9. O'Brien MF. The Cryolife-O'Brien composite aortic stentless xenograft: surgical technique of implantation. Ann Thorac Surg. 1995;60(2 Suppl):S410-3.

10. O'Brien MF. Implantation technique of the Cryolife-O'Brien stentless xenograft aortic valve: the simple, rapid, and correct way to implant and the errors to avoid. Semin Thorac Cardiovasc Surg. 1999;11(4 Suppl 1):121-5.

11. Edmunds LH Jr, Clark RE, Cohn LH, Grunkemeier GL, Miller DC, Weisel RD. Guidelines for reporting morbidity and mortality after cardiac valvular operations. Ad Hoc Liaison Committee for Standardizing Definitions of Prosthetic Heart Valve Morbidity of The American Association for Thoracic Surgery and The Society of Thoracic Surgeons. J Thorac Cardiovasc Surg. 1996;112:708-11.

12. Cheitlin MD, Alpert JS, Armstrong WF, Aurigemma GP, Beller GA, Bierman FZ, et al. ACC/AHA guidelines for the clinical application of echocardiography: executive summary. A report of the American College of Cardiology/American Heart Association Task Force on practice guidelines (Committee on Clinical Application of Echocardiography). Developed in collaboration with the American Society of Echocardiography. J Am Coll Cardiol. 1997;29:862-79.

13. Hvass U, Chatel D, Assayag P, Ouroudji M, Pansard Y, Lenormand C, et al. The O'Brien-Angell stentless porcine valve: early results with 150 implants. Ann Thorac Surg. 1995;60(2 Suppl):S414-7.

14. Jin $X$, Westaby S. Pericardial and porcine stentless aortic valves: are they hemodynamically different? Ann Thorac Surg. 2001;71(5 Suppl): S311-4.

15. Luciani GB, Bertolini P, Mazzucco A. Early failure of freehand aortic stentless xenograft valves. J Thorac Cardiovasc Surg. 1997;113:110910 . 